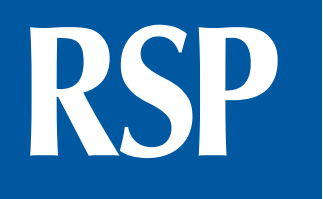

http://www.rsp.fsp.usp.br/
Revista de Saúde Pública

\title{
Quality of infant care in primary health services in Southern and Northeastern Brazil
}

\author{
Andréia Soprani dos Santos', Suele Manjourany Silva Duro", Nágela Valadão Cade"', Luiz Augusto \\ Facchinilv, Elaine Tomasi $^{\mathrm{IV}}$ \\ I Universidade Federal do Espírito Santo. Centro Universitário Norte do Espírito Santo. Departamento de \\ Ciências da Saúde. São Mateus, ES, Brasil \\ " Universidade Federal de Pelotas. Faculdade de Enfermagem. Pelotas, RS, Brasil \\ III Universidade Federal do Espírito Santo. Centro de Ciências da Saúde. Departamento de Enfermagem. Vitória, \\ ES, Brasil \\ Iv Universidade Federal de Pelotas. Departamento de Medicina Social. Pelotas, RS, Brasil
}

\section{Correspondence:}

Andréia Soprani dos Santos

Rodovia BR 101 Norte, Km 60,

Litorâneo

29932-540 São Mateus, ES, Brasil

E-mail: andreia.s.santos@ufes.br

Received: Aug 10, 2016

Approved: Apr 5, 2017

How to cite: Santos AS, Duro SMS, Cade NV, Facchini LA, Tomasi E. Quality of infant care in primary health services in Southern and Northeastern Brazil. Rev Saude Publica. 2018:52:11.

Copyright: This is an open-access article distributed under the terms of the Creative Commons Attribution License, which permits unrestricted use, distribution, and reproduction in any medium, provided that the original author and source are credited.

\section{ABSTRACT}

OBJECTIVE: To assess the quality of the health care provided to children aged under one year old performed by primary health services in the South and Northeast regions of Brazil.

METHODS: This is a cross-sectional, population-based study carried out in 2010 with 7,915 children aged from one to four years, whose homes are located in the areas of health service coverage. We described the prevalence of procedures and guidelines, such as weight and height measurement, vaccination, newborn blood spot screening, evaluation of umbilical cord, instruction on breastfeeding and introduction of new food, and their respective 95\% confidence intervals. The differences were analyzed using the chi-square test of heterogeneity and linear trend. We considered the main outcome of high-quality infant care if the child had received all recommended procedures and guidelines in the first year of life. For this analysis, we used the Poisson regression considering hierarchical model.

RESULTS: There was low prevalence for the instruction on breastfeeding in the first week of life (58.8\%, 95\%CI 57.5-60.0) and on the introduction of new food in the fourth month care. The prevalence of high-quality in childcare was $42.0 \%$ (95\%CI 40.5-43.5). The adjusted analysis according to hierarchical model indicated greater probability of this outcome in the Northeast region ( $\mathrm{PR}=1.17,95 \% \mathrm{CI} 1.09-1.26)$, in smaller municipalities ( $\mathrm{PR}=1.17,95 \% \mathrm{CI} 1.03-1.33$ ), and in municipalities with 50,000 and 99,000 inhabitants ( $\mathrm{PR}=1.20,95 \% \mathrm{CI} 1.09-1.34)$.

CONCLUSIONS: The Northeast region has higher-quality infant care services, which can be explained by the consolidation of the Family Health Strategy in that region.

DESCRIPTORS: Infant. Child Health Services. Quality of Health Care. Primary Health Care. Unified Health System. Family Health Strategy. 


\section{INTRODUCTION}

The monitoring of child development and growth is a primary activity of health professionals, which is a standard practice regarding primary health care for this age group. Thus, childcare service from basic action ${ }^{23}$ has a special position guaranteed in the healthcare policy agenda ${ }^{25}$.

The first years of a child are vital because they are a period of great vulnerability and adaptation to life conditions; ${ }^{3}$ thus, they require continuous monitoring for a consistent promotion of health and prevention of disease ${ }^{23}$. In the context of primary services, the Ministry of Health $(\mathrm{MOH})$ recommends seven routine visits in the first year of life, distributed over the first week and the first, second, fourth, sixth, ninth, and twelfth months ${ }^{20}$. These services prioritize home visits in the early days of birth, instruction on breastfeeding, and control of vaccine-preventable diseases and childhood prevalent diseases ${ }^{10}$.

Infant care services comprise identification and instruction of parents about exclusive breastfeeding and performance of newborn blood spot screening test, analysis and report on weight and height, vaccination, and assessment of danger signs and possible vulnerabilities ${ }^{20}$. These actions, beyond their individual benefits, are able to generate health indicators that detail the profile of the services. Among those indicators, vaccination coverage, which shows the total percentage of children immunized, reflects the result of that service in each territory ${ }^{4}$.

Although care protocols for children are well established, there is still evidence of questionable service performance and variation in the quality ${ }^{5,8,24}$ because of region particularities ${ }^{11}$ and difficulties in implementing health promotion actions ${ }^{12,14,24}$. In that sense, the assessment of services becomes relevant to the organization and management of healthcare.

In Brazil, when considering the socioeconomic and demographic differences between the South and Northeast regions, the latter stands out for its high infant mortality and poverty rates, if compared to the South ${ }^{22}$. Since high quality care reflects on decreasing infant mortality $^{25}$, we expected to find lower quality childcare in the Northeast region. Thus, this study aimed to assess the quality of the health care provided to children aged under one year old performed by primary health services in the South and Northeast regions of Brazil.

\section{METHODS}

This cross-sectional, population-based study was conducted in the Northeast and South regions of Brazil, in areas covered by traditional primary health units (PHU) and Family Health Strategy units (FHS), randomly selected from urban census tracts. We identified in these areas the households with children aged under seven years old and their families. This study is part of the research "Health status, use of services, and quality of care for children and families in the South and Northeast regions of Brazil," carried out from August to October 2010.

The municipalities were randomly selected among those covered between $30 \%$ and $70 \%$ by the Family Health Strategy, and they were stratified into four population scales: 10,000-29,999 inhabitants, 30,000-49,999 inhabitants, 50,000-99,999, and 100,000-999,999. We also randomized the urban PHUs from each random municipality using lists of address identification, care model, and census tracts in their area. For each PHU sampled, two census tracts were chosen: one that included health services and another that was contiguous.

In each sector, for 27 children, the starting point for the location of the households was randomly selected, always systematically jumping five households from the starting point. In each household, all children aged under seven years old were eligible for the study. For this analysis, the sample was restricted to children aged between one and four years, in order to know the full exposure to infant care at the end of the first year and to minimize possible recall bias by the mothers of older children. 
The power of the sample was calculated afterwards, considering $42 \%^{5}$ for high quality prevalence of infant care services, that is if the child had received all the procedures recommended for the first year of life, margin for error of 1.7 percentage points, and a design effect of 2.0, adding up to 6,456 children. To verify the association between high quality childcare and household area, we used a significance level of 5\%, power of $95 \%$, exposed and unexposed rate of 1.0, prevalence of outcome among those unexposed of $40 \%$, and prevalence rate of 1.13, amounting to 4,674 children. In addition to this number, we added $10 \%$ for losses or refusals and $30 \%$ for the control of confounding factors, resulting in 6,545 children. In total, 7,915 children aged from one to four years integrated the sample.

From the procedures performed - heel prick test, evaluation of the umbilical cord, vaccination, measurement, and instruction on weight and height, breastfeeding, and introduction of new foods -, a variable was constructed with the sum of the positive responses to all items in each of the seven of the services recommended in the first year of life.

Subsequently, a high-quality childbirth outcome variable was constructed if the child had received all the procedures and guidelines recommended in the first year of life.

The independent variables were geographic location: region (South, Northeast), size of the city in thousands of inhabitants (10-29, 30-49, 50-99, and 100-999), care model (family healthcare, traditional care); family socioeconomic status: economic classification of the Brazilian Association of Research Companies (ABEP - A/B, C, D/E), household income per capita in quartiles of minimum wages (up to $0.237,0.238-0.431,0.432-0.823,0.824$ or more), Bolsa Família - a Brazilian social welfare program - (yes, no); maternal demographic and social condition: age in years (up to 19, 20-29, 30-39, 40 or more), self-reported race (white, brown, black), school education in years (up to 4, 5-8, 9 or more), presence of spouse/partner (yes, no), total number of live births (1,2,3, or more); child status: total number of prenatal appointments (up to 5,6 or more), sex (male, female), age in years $(1,2,3,4)$, race reported by the mother (white, brown, black).

Data collection was carried out by trained interviewers with the aid of a personal digital assistant (PDA). We used an individual questionnaire containing information on children and their mothers, as well as a socioeconomic questionnaire with information about the household and family. Interviews took place in the households and were answered by the biological mother or, in her absence, by a responsible guardian. For quality control, $8 \%$ of the interviews were repeated, when the sample answered again four questions about the child and family. Kappa statistics showed rates between 0.6 and 0.9, understood as good and excellent concordance, respectively ${ }^{16}$.

We calculated the prevalence and respective 95\% confidence intervals (95\%CI) for all procedures and instructions in the seven childcare appointments. We performed a bivariate analysis calculating the prevalence and associations with chi-square test of heterogeneity and linear trend. Poisson regression was used for the crude and adjusted analysis of the primary outcome, with robust adjustment of variance and prevalence ratios (PR), as well as 95\% CI estimated by Wald test for heterogeneity and linear trend. The adjusted analysis was guided by hierarchical model with backward elimination. The input of variables happened by levels, considering the value $p<0.20$, identified in the crude analysis. We included the geographic location of the variables in the distal level; the socioeconomic variables in the second one; and those related to maternal demographic and social characteristics, followed by the addition of proximal variables related to the child characteristics in the third level. At each level, the variables were adjusted among themselves and to higher levels. For all analysis, a 5\% significance level was adopted. All data analyses were conducted using Stata 13.0.

This research was approved by the Ethics Committee of the Faculdade de Medicina of the Universidade Federal de Pelotas, registered under document number 133/09 in December 21, 2009. The informed consent was signed by all interviewees. 


\section{RESULTS}

In total, this sample consisted of 7,915 children aged one to four years, with predominance of residents in the Northeast region (51.0\%), in municipalities with more than 100,000 inhabitants (59.7\%), and in areas covered by FHS (81.8\%). Most children belonged to families from economic class C (53.0\%), half had an average monthly income per capita of less than 0.43 minimum wage (minimum wage value at the time was $\mathrm{R} \$ 358.35$, equivalent to US\$203.72), and 35.1\% were part of the Bolsa Familia Program. More than half of the mothers were $20-29$ years old (52.7\%), $46.7 \%$ self-reported as white, $54.1 \%$ self-reported having nine or more years of school education, $78.8 \%$ lived with a spouse/partner, and $43.8 \%$ had only one child born alive. Regarding children, $85.7 \%$ were monitored in prenatal care with six or more visits, $52.0 \%$ were male, and $52.7 \%$ were white. The age factor was distributed equally among the four chosen years (Table 1).

On the first week of life, the recommended actions were offered to more than $90 \%$ of the children, apart from instruction on breastfeeding, which reached only over half the sample. Except for instruction on breastfeeding, all actions were more frequent in the Southern Brazil. Instruction on the introduction of new foods had prevalence under $75.0 \%$ until the fourth-month appointment, increasing its results in the sixth-month appointment to $92.5 \%$ (95\%CI 91.8-93.2). The prevalence related to the other actions was approximated in both regions. From the ninth-month of service onwards, information regarding instruction on breastfeeding and introduction of new foods were collected simultaneously, especially in the Northeast region (Table 2).

Table 3 presents the prevalence of high quality childcare in each period. In the first week, $55.3 \%$ of the children had weight and height measurements, guidelines on breastfeeding, performance of the heel prick test, and evaluation of the umbilical cord.

Quality of infant care ranged from 55.3\% in the first week appointment to $93.6 \%$ in the twelfth-month appointment, with linear growth in the period. Quality of care was better shown in the Northeast region in all seven visits, performance that increased in both regions throughout the period. Municipality size above 100,000 inhabitants influenced the ninth-month visit. The same was observed in relation to the care model of health facilities in the twelfth-month visit. There were socioeconomic differences among classes (A/B, C, D/E) starting from the sixth-month appointment. Regarding income per capita, the differences were visible in the first-, second-, sixth-, and ninth-month appointments. Children who benefited from Bolsa Familia also represented better quality performance in the second- and ninth-month appointments (Table 3).

We observed a higher prevalence of high quality childcare in mothers aged over 39 years in the fourth- and twelfth-month appointment; the greatest difference was found in the fourth-month appointment among mothers aged under 20 years (65.8\%) and mothers aged over 39 years $(75.0 \%)$. In both periods, the children of mothers aged up to 19 years had the lowest proportions of high quality (Table 3 ).

Children reported as brown and black by the mothers showed differences in the prevalence of quality in childcare in the first three appointments. A similar situation was identified regarding maternal education, whose contrast was observed in the sixth- and ninth-month appointment. Maternal characteristics related to the presence of spouse/partner and the number of live births showed insignificant results in association with the quality of childcare services. Mothers who had six or more prenatal appointments reported superior quality in three appointments. Regarding children, sex and age did not show significant differences. Race, on its turn, influenced the first three appointments (Table 3).

The prevalence of high quality childcare, considering all seven appointments in the first year of life, added up to $42.0 \%$ (95\%CI 40.5-43.5). The adjusted analysis, according to the hierarchical model, showed upper prevalence of high quality in the Northeast region $(\mathrm{PR}=1.17$, 95\%CI 1.09-1.26), in smaller municipalities ( $\mathrm{PR}=1.17,95 \% \mathrm{CI} 1.03-1.33$ ), and in the group of 
Table 1. Description of the sample according to demographic, socioeconomic, maternal, and child variables. Southern and Northeastern Brazil, 2010.

\begin{tabular}{|c|c|c|}
\hline Variable & $\mathbf{n}$ & $\%$ \\
\hline \multicolumn{3}{|l|}{ Region $(\mathrm{n}=7,915)$} \\
\hline Northeast & 4,041 & 51.0 \\
\hline South & 3,874 & 49.0 \\
\hline \multicolumn{3}{|c|}{ Municipality size in thousands of inhabitants $(n=7,915)$} \\
\hline $10-29$ & 621 & 7.8 \\
\hline $30-49$ & 1,565 & 19.8 \\
\hline $50-99$ & 1,004 & 12.7 \\
\hline 100-999 & 4,725 & 59.7 \\
\hline \multicolumn{3}{|l|}{ Care model $(\mathrm{n}=7,915)$} \\
\hline Family Healh Strategy & 6,478 & 81.8 \\
\hline Traditional care & 1,437 & 18.2 \\
\hline \multicolumn{3}{|c|}{ Economic classification $(\mathrm{n}=7,455)$} \\
\hline A or B & 1,575 & 21.1 \\
\hline $\mathrm{C}$ & 3,951 & 53.0 \\
\hline $\mathrm{D}$ or $\mathrm{E}$ & 1,929 & 25.9 \\
\hline \multicolumn{3}{|c|}{ Income per capita in quartiles in minimum wage $(n=7.806)$} \\
\hline$\leq 0.237$ & 1,767 & 24.9 \\
\hline $0.238-0.431$ & 1,771 & 25.0 \\
\hline $0.432-0.823$ & 1,783 & 25.2 \\
\hline$\geq 0.824$ & 1,765 & 24.9 \\
\hline \multicolumn{3}{|c|}{ Social welfare program Bolsa Família $(\mathrm{n}=7,777)$} \\
\hline Yes & 2,728 & 35.1 \\
\hline No & 5,049 & 64.9 \\
\hline \multicolumn{3}{|c|}{ Maternal age in years $(n=5,883)$} \\
\hline$\leq 19$ & 469 & 8.0 \\
\hline $20-29$ & 3,098 & 52.7 \\
\hline $30-39$ & 1,875 & 31.8 \\
\hline$\geq 40$ & 441 & 7.5 \\
\hline \multicolumn{3}{|l|}{ Maternal race $(n=5,861)$} \\
\hline White & 2,739 & 46.7 \\
\hline Brown & 998 & 17.0 \\
\hline Black & 2,124 & 36.3 \\
\hline \multicolumn{3}{|c|}{ Maternal school education in years $(n=5,582)$} \\
\hline$\leq 4$ & 643 & 11.5 \\
\hline $5-8$ & 1,919 & 34.4 \\
\hline$\geq 9$ & 3,020 & 54.1 \\
\hline \multicolumn{3}{|c|}{ Presence of spouse/partner $(n=5,880)$} \\
\hline Yes & 4,633 & 78.8 \\
\hline No & 1,247 & 21.2 \\
\hline \multicolumn{3}{|c|}{ Number of live births ( $n=5,893$ ) } \\
\hline 1 & 2,578 & 43.8 \\
\hline 2 & 1,924 & 32.6 \\
\hline$\geq 3$ & 1,391 & 23.6 \\
\hline \multicolumn{3}{|c|}{ Number of prenatal appointments $(n=7,102)$} \\
\hline$\leq 5$ & 1,016 & 14.3 \\
\hline$\geq 6$ & 6,086 & 85.7 \\
\hline \multicolumn{3}{|l|}{ Sex of the child $(n=7,915)$} \\
\hline Male & 4,114 & 52.0 \\
\hline Female & 3,801 & 48.0 \\
\hline \multicolumn{3}{|c|}{ Age of the child in years $(n=7,915)$} \\
\hline 1 & 2,070 & 26.2 \\
\hline 2 & 1,968 & 24.8 \\
\hline 3 & 1,943 & 24.6 \\
\hline 4 & 1,934 & 24.4 \\
\hline \multicolumn{3}{|l|}{ Race of the child $(n=7,825)$} \\
\hline White & 4,123 & 52.7 \\
\hline Brown & 1,576 & 20.1 \\
\hline Black & 2,126 & 27.2 \\
\hline
\end{tabular}


Table 2. Prevalence of procedures and health guidelines developed in infant care services in the first year of life, according to region. Southern and Northeastern Brazil, 2010.

\begin{tabular}{|c|c|c|c|c|}
\hline \multirow{3}{*}{ Variable } & & \multicolumn{2}{|c|}{ Region $(\mathbf{n}=7,915)$} & \multirow[b]{2}{*}{ Total } \\
\hline & & $\begin{array}{c}\text { South } \\
(n=3,874)\end{array}$ & $\begin{array}{l}\text { Northeast } \\
(n=4,041)\end{array}$ & \\
\hline & & & & \\
\hline \multirow{5}{*}{ 1st week } & Weight measurement & $98.7(98.2-99.0)$ & $97.1(96.4-97.6)$ & $97.9(97.5-98.3)$ \\
\hline & Height measurement & $98.5(98.0-98.8)$ & $96.0(95.3-96.7)$ & $97.3(97.0-97.7)$ \\
\hline & Instruction on breastfeeding & $53.5(51.8-55.2)$ & $64.6(62.9-66.3)$ & $58.8(57.5-60.0)$ \\
\hline & Blood spot screening test & $99.0(98.6-99.3)$ & $94.0(93.1-94.8)$ & $96.7(96.2-97.1)$ \\
\hline & Evaluation of the umbilical cord & $93.3(92.4-94.1)$ & $87.4(86.2-88.5)$ & $90.6(89.8-91.3)$ \\
\hline \multirow{7}{*}{1 month } & Weight & $99.7(99.5-99.9)$ & $99.5(99.1-99,7)$ & $99.6(99.4-99.8)$ \\
\hline & Weight report & $97.5(96.9-98.0)$ & $97.6(97.0-98,1)$ & $97.5(97.1-97.9)$ \\
\hline & Height & $99.2(98.9-99.5)$ & $97.0(98.9-99,5)$ & $98.2(97.9-98.5)$ \\
\hline & Height report & $97.4(96.8-97.9)$ & $98.2(97.6-98,6)$ & $97.8(97.4-98.1)$ \\
\hline & Vaccination & 98.8 (98.4-99.1) & $98.7(98.2-99,0)$ & $98.8(98.5-99.0)$ \\
\hline & Instruction on breastfeeding & $91.8(90.8-92.7)$ & $93.7(92.8-94,5)$ & $92.7(92.0-93.3)$ \\
\hline & Introduction of new foods & $59.9(58.3-61.6)$ & $66.1(64.4-67,9)$ & $62.8(61.6-64.0)$ \\
\hline \multirow{7}{*}{2 months } & Weight measurement & $99.6(99.4-99.8)$ & $99.3(98.9-99.6)$ & $99.5(99.3-99.6)$ \\
\hline & Weight report & $97.5(96.9-98.0)$ & $97.9(97.3-98.4)$ & $97.7(97.3-98.0)$ \\
\hline & Height measurement & $99.0(98.7-99.3)$ & $96.9(96.3-97.5)$ & $98.1(97.7-98.4)$ \\
\hline & Height report & $97.3(96.7-97.8)$ & $98.5(97.9-98.9)$ & $97.8(97.4-98.2)$ \\
\hline & Vaccination & $98.8(98.4-99.1)$ & $98.8(98.4-99.2)$ & $98.8(98.5-99.1)$ \\
\hline & Instruction on breastfeeding & $92.2(91.3-93.1)$ & 95.7 (94.9-96.4) & $93.8(93.2-94.4)$ \\
\hline & Introduction of new foods & $62.0(60.3-63.6)$ & $70.1(68.4-71.7)$ & $65.7(64.5-66.9)$ \\
\hline \multirow{7}{*}{4 months } & Weight measurement & $99.6(99.3-99.8)$ & $99.5(99.1-99.7)$ & $99.5(99.3-99.7)$ \\
\hline & Weight report & $97.3(96.7-97.8)$ & $98.0(97.4-98.4)$ & $97.6(97.2-98.0)$ \\
\hline & Height measurement & $98.9(98.4-99.2)$ & $97.3(96.6-97.8)$ & $98.1(97.8-98.5)$ \\
\hline & Height report & $97.4(96.8-97.9)$ & $98.3(97.7-98.7)$ & $97.8(97.4-98.2)$ \\
\hline & Vaccination & $98.7(98.3-99.0)$ & $99.0(98.6-99.3)$ & $98.9(98.6-99.1)$ \\
\hline & Instruction on breastfeeding & $92.7(91.8-93.6)$ & $95.5(94.7-96.2)$ & $94.0(93.4-94.6)$ \\
\hline & Introduction of new foods & $70.8(69.2-72.3)$ & $74.4(72.8-76.0)$ & $72.5(71.3-73.6)$ \\
\hline \multirow{7}{*}{6 months } & Weight measurement & $99.6(99.3-99.8)$ & $99.6(99.3-99.8)$ & $99.6(99.4-99.7)$ \\
\hline & Weight report & $97.6(97.0-98.0)$ & $98.0(97.4-98.4)$ & $97.8(97.4-98.1)$ \\
\hline & Height measurement & $98.8(98.3-99.1)$ & $97.1(96.4-97.7)$ & $98.0(97.6-98.3)$ \\
\hline & Height report & $97.5(97.0-98.0)$ & $98.4(97.9-98.8)$ & $97.9(97.5-98.3)$ \\
\hline & Vaccination & $99.1(98.8-99.4)$ & $98.7(98.2-991)$ & $99.0(98.7-99.2)$ \\
\hline & Instruction on breastfeeding & $92.9(92.0-93.7)$ & $95.5(94.6-96.2)$ & $94.1(93.5-94.7)$ \\
\hline & Introduction of new foods & $91.4(90.4-92.2)$ & $93.8(92.8-94.6)$ & $92.5(91.8-93.2)$ \\
\hline \multirow{6}{*}{9 months } & Weight measurement & $99.6(99.3-99.8)$ & $99.4(99.0-99.6)$ & $99.5(99.3-99.7)$ \\
\hline & Weight report & $97.3(97.0-98.1)$ & $98.0(97.4-98.5)$ & $97.8(97.4-98.2)$ \\
\hline & Height measurement & $99.0(98.6-99.3)$ & $97.1(96.4-97.7)$ & $98.2(97.8-98.5)$ \\
\hline & Height report & $97.5(96.9-98.0)$ & $98.4(97.8-98.8)$ & $97.9(97.5-98.3)$ \\
\hline & Vaccination & $99.0(98.6-99.3)$ & 98.7 (98.2-99.0) & $98.9(98.6-99.1)$ \\
\hline & $\begin{array}{l}\text { Breastfeeding and introduction } \\
\text { of new foods }\end{array}$ & $92.6(91.7-93.4)$ & $95.3(94.4-96.0)$ & $93.8(93.2-94.4)$ \\
\hline \multirow{6}{*}{12 months } & Weight measurement & $99.4(99.1-99.7)$ & 99.5 (99.2-99.7) & $99.5(99.3-99.6)$ \\
\hline & Weight report & $97.5(97.0-98.0)$ & $98.3(97.7-98.7)$ & $97.9(97.5-98.2)$ \\
\hline & Height measurement & 98.7 (98.3-99.1) & $97.0(96.2-97.5)$ & $97.9(97.5-98.3)$ \\
\hline & Height report & $97.7(97.1-98.2)$ & 98.5 (98.0-98.9) & $98.1(97.7-98.4)$ \\
\hline & Vaccination & $99.0(98.6-99.3)$ & 98.7 (98.2-99.0) & $98.9(98.6-99.1)$ \\
\hline & $\begin{array}{l}\text { Breastfeeding and introduction } \\
\text { of new foods }\end{array}$ & $92.4(91.4-93.3)$ & $95.6(94.7-96.3)$ & $93.9(93.2-94.5)$ \\
\hline
\end{tabular}


Table 3. Prevalence of high quality outcome of child care in different periods, according to demographic, socioeconomic, maternal, and child variables. Southern and Northeastern Brazil, 2010.

\begin{tabular}{|c|c|c|c|c|c|c|c|}
\hline \multirow{2}{*}{ Variable } & 1st week & 1 month & 2 months & 4 months & 6 months & 9 months & 12 months \\
\hline & $\%$ & $\%$ & $\%$ & $\%$ & $\%$ & $\%$ & $\%$ \\
\hline Region $(n=7,915)^{a}$ & $<0.000$ & $<0.000$ & $<0.000$ & $<0.000$ & 0.001 & 0.005 & $<0.000$ \\
\hline Northeast & 58.9 & 64.1 & 69.1 & 73.6 & 91.8 & 94.3 & 95.1 \\
\hline South & 52.1 & 57.7 & 60.4 & 69.1 & 89.3 & 92.4 & 92.5 \\
\hline Municipality size in thousands of inhabitants $(n=7,915)^{b}$ & 0.877 & 0.206 & 0.066 & 0.154 & 0.066 & 0.009 & 0.090 \\
\hline $10-29$ & 55.7 & 66.0 & 71.0 & 76.7 & 89.7 & 93.0 & 94.1 \\
\hline $30-49$ & 56.4 & 59.8 & 63.1 & 68.4 & 88.8 & 91.2 & 91.9 \\
\hline $50-99$ & 52.1 & 60.7 & 66.5 & 77.0 & 91.3 & 93.3 & 93.7 \\
\hline 100-999 & 55.6 & 60.3 & 63.6 & 70.2 & 90.9 & 94.0 & 94.1 \\
\hline Care model $(n=7,915)^{\mathrm{a}}$ & 0.234 & 0.501 & 0.807 & 0.590 & 0.104 & 0.669 & 0.046 \\
\hline Family Healh Strategy & 55.7 & 60.4 & 64.5 & 71.0 & 90.1 & 93.2 & 93.3 \\
\hline Traditional care & 53.8 & 61.5 & 64.1 & 71.8 & 91.7 & 93.6 & 94.9 \\
\hline Economic classification $(\mathrm{n}=7,455)^{\mathrm{b}}$ & 0.513 & 0.889 & 0.230 & 0.126 & 0.006 & $<0.000$ & 0.005 \\
\hline$A$ or $B$ & 56.3 & 61.7 & 64.2 & 73.5 & 92.8 & 95.9 & 95.5 \\
\hline $\mathrm{C}$ & 54.8 & 59.5 & 62.9 & 69.8 & 89.7 & 92.4 & 92.7 \\
\hline $\mathrm{D}$ or $\mathrm{E}$ & 55.1 & 61.1 & 66.6 & 71.0 & 88.9 & 91.8 & 92.9 \\
\hline Income per capita in quartiles in minimum wage $(\mathrm{n}=7.806)^{\mathrm{b}}$ & 0.063 & $<0.000$ & $<0.000$ & 0.057 & 0.014 & 0.002 & 0.093 \\
\hline$\leq 0.237$ & 56.4 & 64.7 & 69.5 & 73.3 & 88.5 & 91.3 & 92.7 \\
\hline $0.238-0.431$ & 55.1 & 61.2 & 64.7 & 70.3 & 89.8 & 92.6 & 92.8 \\
\hline $0.432-0.823$ & 55.2 & 58.0 & 62.2 & 69.7 & 91.4 & 93.8 & 93.7 \\
\hline$\geq 0.824$ & 52.7 & 56.3 & 59.7 & 69.8 & 91.0 & 94.3 & 94.2 \\
\hline Social welfare program Bolsa Família $(\mathrm{n}=7,777)^{\mathrm{a}}$ & 0.149 & 0.081 & 0.010 & 0.685 & 0.195 & 0.023 & 0.365 \\
\hline Yes & 56.6 & 62.0 & 66.5 & 71.3 & 89.7 & 92.1 & 93.1 \\
\hline No & 54.7 & 59.7 & 63.1 & 70.8 & 90.7 & 93.8 & 93.8 \\
\hline Maternal age in years $(n=5,883)^{b}$ & 0.683 & 0.062 & 0.454 & 0.016 & 0.299 & 0.217 & 0.009 \\
\hline$\leq 19$ & 49.7 & 57.1 & 62.8 & 65.8 & 88.8 & 89.7 & 90.7 \\
\hline $20-29$ & 54.9 & 59.1 & 63.6 & 70.5 & 90.5 & 93.5 & 93.2 \\
\hline $30-39$ & 53.1 & 60.2 & 63.4 & 71.3 & 90.7 & 93.9 & 94.5 \\
\hline$\geq 40$ & 51.4 & 63.9 & 66.6 & 75.0 & 91.4 & 92.4 & 94.6 \\
\hline Maternal race $(\mathrm{n}=5,861)^{\mathrm{a}}$ & 0.040 & 0.008 & 0.001 & 0.459 & 0.084 & 0.114 & 0.220 \\
\hline White & 52.0 & 57.4 & 60.9 & 70.0 & 90.1 & 93.1 & 93.2 \\
\hline Brown & 57.0 & 61.5 & 67.2 & 72.2 & 89.2 & 91.9 & 92.7 \\
\hline Black & 54.5 & 62.0 & 66.0 & 71.1 & 91.8 & 94.2 & 94.4 \\
\hline Maternal school education in years $(\mathrm{n}=5,582)^{\mathrm{b}}$ & 0.711 & 0.785 & 0.478 & 0.219 & 0.016 & 0.036 & 0.121 \\
\hline$\leq 4$ & 54.7 & 59.1 & 62.9 & 71.0 & 91.3 & 94.1 & 94.1 \\
\hline $5-8$ & 52.2 & 61.1 & 65.0 & 71.3 & 90.3 & 93.1 & 93.1 \\
\hline$\geq 9$ & 54.1 & 58.1 & 63.1 & 67.0 & 87.7 & 91.5 & 92.5 \\
\hline Presence of spouse/partner $(n=5,880)^{a}$ & 0.230 & 0.227 & 0.044 & 0.383 & 0.668 & 0.662 & 0.310 \\
\hline Yes & 53.2 & 59.2 & 63.0 & 70.5 & 90.4 & 93.2 & 93.3 \\
\hline No & 55.4 & 61.4 & 66.6 & 72.0 & 90.9 & 93.6 & 94.3 \\
\hline Number of live births $(n=5,893)^{b}$ & 0.446 & 0.536 & 0.892 & 0.457 & 0.074 & 0.023 & 0.235 \\
\hline 1 & 53.3 & 58.5 & 64.0 & 70.7 & 90.8 & 93.7 & 93.7 \\
\hline 2 & 53.4 & 61.8 & 63.4 & 71.9 & 91.5 & 94.2 & 94.4 \\
\hline$\geq 3$ & 54.8 & 58.9 & 63.8 & 69.0 & 88.4 & 91.2 & 92.2 \\
\hline Number of prenatal appointments $(\mathrm{n}=7,102)^{\mathrm{b}}$ & 0.526 & 0.038 & 0.025 & 0.781 & 0.016 & $<0.000$ & $<0.000$ \\
\hline$\leq 5$ & 53.4 & 63.5 & 67.6 & 70.1 & 87.7 & 89.7 & 90.0 \\
\hline$\geq 6$ & 54.6 & 59.4 & 63.2 & 70.6 & 90.6 & 93.6 & 93.9 \\
\hline Sex of the child $(n=7,915)^{a}$ & 0.319 & 0.783 & 0.970 & 0.229 & 0.301 & 0.524 & 0.080 \\
\hline Male & 55.9 & 60.5 & 64.4 & 71.8 & 90.1 & 93.1 & 93.1 \\
\hline Female & 54.6 & 60.8 & 64.4 & 70.4 & 90.9 & 93.5 & 94.2 \\
\hline Age of the child in years $(n=7,915)^{b}$ & 0.951 & 0.626 & 0.558 & 0.669 & 0.431 & 0.942 & 0.747 \\
\hline 1 & 55.2 & 60.7 & 65.4 & 70.7 & 90.8 & 93.3 & 93.9 \\
\hline 2 & 55.4 & 60.0 & 64.1 & 71.7 & 90.0 & 93.0 & 93.1 \\
\hline 3 & 55.6 & 60.3 & 63.4 & 70.4 & 91.3 & 93.9 & 94.4 \\
\hline 4 & 55.0 & 61.6 & 64.6 & 71.8 & 89.5 & 93.0 & 93.2 \\
\hline Race of the children $(n=7,825)^{a}$ & 0.001 & 0.005 & 0.001 & 0.361 & 0.506 & 0.132 & 0.246 \\
\hline White & 53.3 & 58.8 & 62.3 & 70.4 & 90.1 & 92.9 & 93.2 \\
\hline Brown & 56.5 & 62.4 & 66.5 & 72.5 & 91.1 & 93.1 & 94.0 \\
\hline Black & 58.5 & 63.2 & 67.4 & 71.6 & 90.9 & 94.5 & 94.5 \\
\hline Total & 55.3 & 60.6 & 64.4 & 71.1 & 90.4 & 93.3 & 93.6 \\
\hline
\end{tabular}

${ }^{a}$ Chi-square test of heterogeneity.

${ }^{\mathrm{b}}$ Chi-square test of linear trend. 
50,000-99,999 inhabitants ( $\mathrm{PR}=1.20,95 \% \mathrm{CI} 1.09-1.34$ ). The other variables of the model, when submitted to adjustment in each level among themselves and in the levels among those with $\mathrm{p}<0.05$, did not show association with the quality of childcare services (Table 4).

\section{DISCUSSION}

The prevalence of procedures and health instructions received in infant care services indicated, in most cases, that PHU and FHS in the Northeast and South regions of Brazil have conducted the recommended health actions. The higher prevalence for measures of weight and height, greater than $97.0 \%$, for all visits, suggests that health professionals have performed the anthropometric measures, which are important for the evaluation of child growth ${ }^{23}$. In a country where child obesity rates rise quickly, that practice reveals itself to be even more necessary and propitious for preventing childhood and adult chronic diseases ${ }^{15,21}$. Vaccination, on its turn, also stands out for presenting elevated prevalence, reflecting a well-structured and organized National Immunization Policy (NIP), which has been providing Brazilians with all types of vaccines. The NIP displays an efficient coverage, represented by its high rates even among low income populations ${ }^{4}$, which presupposes no obstacles to its access.

The low prevalence concerning instruction on breastfeeding carried out in the first-week appointment is alarming, as it is a critical period for the consolidation of breastfeeding, with information on baby sucking and feeding on demand ${ }^{26}$. All this information is essential to support the breastfeeding practice and to ensure proper weight gain to be evaluated in subsequent appointments. When that instruction is not considered, it deconstructs a preventive practice recommended over the years, which admittedly benefits the mother and baby $^{26}$. Although this study has not investigated the reasons for such low prevalence, it represents a real drawback that seems to reside not in the absence of equipment but in the incompleteness of the service.

The professional responsible for infant care must guide and instruct the mothers and families of the children on the adoption of recommended behaviors ${ }^{23}$. The lack of professional training and understanding about the importance of appropriate monitoring of child growth may reflect gaps in service and result in failure to give instructions and guidelines to parents ${ }^{6,7,12}$.

In this study, the prevalence of instructions on the introduction of new foods met the standard recommended for feeding infants aged under six month $\mathrm{s}^{20}$, being reduced in the first sessions, and followed by an increase in the sixth-month visit. From the first day of birth to the sixth month of the child's life, health professionals should not advise the ingestion of food other than breast milk ${ }^{18}$; after this period, it is necessary to instruct parents about the transition from exclusive breastfeeding to the beginning of ingestion of other foods ${ }^{18}$. It is noteworthy that this study did not set out to identify the duration of breastfeeding but the instruction provided by health professionals to parents in infant care services.

Brazilian studies have assessed the quality of childcare by completing health booklets, recording information on files, counting anthropometric measures, and performing procedures according to service protocols, as well as by national research. An overview of this situation is displayed by the minor prevalence of the completion of growth charts ${ }^{1}$ and health booklets. The prevalence of appointments offered to children has been less than $60 \%^{10,15}$, reaching less than $30 \%$ for the first-week appointment of the newborn ${ }^{5,15}$. Blood spot screening test has been carried out in $70.8 \%$ of the children and the three doses of the tetravalent vaccine has reached $75.9 \%^{15}$. In general, we observed little favorable conditions for good quality of infant healthcare $\mathrm{r}^{1,5,7-11,17,19}$.

When assessing the prevalence of high quality childcare throughout the seven sessions, in the first-week, first-, second- and fourth-month appointments, we observed that children were not entirely covered by the recommended health actions in the period. Reduced prevalence of instruction on breastfeeding and introduction of new foods may have affected this result. 
Table 4. Crude and adjusted analysis of factors associated with high quality infant care services. Southern and Northeastern Brazil, 2010.

\begin{tabular}{|c|c|c|c|c|c|}
\hline \multirow{2}{*}{ Variable } & \multirow{2}{*}{$\%$} & \multicolumn{2}{|c|}{ Crude analysis $^{a}$} & \multicolumn{2}{|c|}{ Adjusted analysis $^{\mathrm{a}}$} \\
\hline & & $\operatorname{RP}(95 \% \mathrm{Cl})$ & $\mathbf{p}$ & RP $(95 \% \mathrm{CI})$ & p \\
\hline Region $(n=7,915)^{b}$ & & & $<0.000$ & & $<0.000$ \\
\hline Northeast & 45.3 & $1.14(1.06-1.22)$ & & $1.17(1.09-1.26)$ & \\
\hline South & 39.8 & 1.0 & & 1.0 & \\
\hline Municipality size in thousands of inhabitants $(n=7,915)^{\mathrm{b}}$ & & & 0.017 & & 0.018 \\
\hline $10-29$ & 47.3 & $1.17(1.03-1.33)$ & & $1.17(1.03-1.33)$ & \\
\hline $30-49$ & 42.4 & $1.05(0.96-1.15)$ & & $1.03(0.95-1.14)$ & \\
\hline 50-99 & 46.2 & $1.14(1.03-1.27)$ & & $1.20(1.09-1.34)$ & \\
\hline 100-999 & 40.4 & 1.0 & & 1.0 & \\
\hline Care model $(\mathrm{n}=7,915)^{\mathrm{c}}$ & & & 0.306 & & \\
\hline Family Health Strategy & 42.4 & $1.05(0.95-1.14)$ & & & \\
\hline Traditional care & 40.5 & 1.0 & & & \\
\hline Economic classification $(n=7,455)^{c}$ & & & 0.240 & & \\
\hline $\mathrm{A}$ or $\mathrm{B}$ & 41.4 & 1.0 & & & \\
\hline $\mathrm{C}$ & 41.0 & $0.99(0.91-1.08)$ & & & \\
\hline D or $E$ & 44.4 & $1.07(0.97-1.19)$ & & & \\
\hline Income per capita in quartiles in minimum wage $(\mathrm{n}=7.806)^{\mathrm{b}}$ & & & 0.001 & & 0.100 \\
\hline$\leq 0.237$ & 44.2 & $1.18(1.06-1.32)$ & & $1.10(0.96-1.26)$ & \\
\hline $0.238-0.431$ & 44.0 & $1.18(1.06-1.31)$ & & $1.13(1.00-1.27)$ & \\
\hline $0.432-0.823$ & 41.3 & $1.11(0.99-1.23)$ & & $1.10(0.99-1.22)$ & \\
\hline$\geq 0.824$ & 37.3 & 1.0 & & 1.0 & \\
\hline Social welfare program Bolsa Família $(\mathrm{n}=7,777)^{\mathrm{b}}$ & & & 0.189 & & 0.745 \\
\hline Yes & 43.4 & $1.05(0.98-1.13)$ & & $0.98(0.89-1.08)$ & \\
\hline No & 41.3 & 1.0 & & 1.0 & \\
\hline Maternal age in years $(n=5,883)^{c}$ & & & 0.738 & & \\
\hline$\leq 19$ & 37.1 & 1.0 & & & \\
\hline $20-29$ & 41.0 & $1.11(0.92-1.32)$ & & & \\
\hline $30-39$ & 39.6 & $1.07(0.89-1.29)$ & & & \\
\hline$\geq 40$ & 38.2 & $1.03(0.82-1.31)$ & & & \\
\hline Maternal race $(\mathrm{n}=5,861)^{\mathrm{b}}$ & & & 0.148 & & 0.961 \\
\hline White & 38.6 & 1.0 & & 1.0 & \\
\hline Brown & 43.0 & $1.11(0.99-1.25)$ & & $1.02(0.88-1.18)$ & \\
\hline Black & 41.1 & $1.07(0.97-1.17)$ & & $0.99(0.89-1.12)$ & \\
\hline Maternal school education in years $(n=5,582)^{c}$ & & & 0.566 & & \\
\hline$\leq 4$ & 39.6 & $1.00(0.87-1.16)$ & & & \\
\hline $5-8$ & 41.4 & $1.05(0.96-1.15)$ & & & \\
\hline$\geq 9$ & 39.4 & 1.0 & & & \\
\hline Presence of spouse/partner $(\mathrm{n}=5,880)^{\mathrm{b}}$ & & & 0.105 & & 0.138 \\
\hline Yes & 39.4 & 1.0 & & 1.0 & \\
\hline No & 42.8 & $1.09(0.98-1.20)$ & & $1.08(0.97-1.21)$ & \\
\hline Number of live births $(n=5,893)^{c}$ & & & 0.956 & & \\
\hline 1 & 38.8 & 1.0 & & & \\
\hline 2 & 43.6 & $1.05(0.96-1.16)$ & & & \\
\hline$\geq 3$ & 40.8 & $0.98(0.88-1.10)$ & & & \\
\hline Number of prenatal appointments $(n=7,102)^{c}$ & & & 0.258 & & \\
\hline$\leq 5$ & 39.5 & 1.0 & & & \\
\hline$\geq 6$ & 41.6 & $0.94(0.83-1.05)$ & & & \\
\hline Sex of the child $(n=7,915)^{b}$ & & & 0.122 & & 0.074 \\
\hline Male & 43.1 & $1.06(0.99-1.13)$ & & $1.09(0.99-1.19)$ & \\
\hline Female & 40.8 & 1.0 & & 1.0 & \\
\hline Age of the child in years $(n=7,915)^{c}$ & & & 0.964 & & \\
\hline 1 & 41.4 & $1.00(0.91-1.11)$ & & & \\
\hline 2 & 42.6 & $1.03(0.94-1.14)$ & & & \\
\hline 3 & 42.9 & $1.04(0.94-1.15)$ & & & \\
\hline 4 & 41.2 & 1.0 & & & \\
\hline Race of the child $(n=7,825)^{b}$ & & & $<0.000$ & & 0.128 \\
\hline White & 39.5 & 1.0 & & 1.0 & \\
\hline Brown & 42.2 & $1.07(0.97-1.18)$ & & $0.96(0.82-1.12)$ & \\
\hline Black & 47.2 & $1.20(1.10-1.30)$ & & $1.11(0.97-1.26)$ & \\
\hline Total & 42.0 & & & & \\
\hline
\end{tabular}

a Poisson Regression with robust variance.

${ }^{b}$ At each level, the variables were adjusted to each other and to higher levels, according to a hierarchical model.

c Variables not included in the adjusted model (value $p>0.20$ in the crude analysis). 
It is also possible that health teams have failed to achieve certain basic procedures ${ }^{12}$. On the other hand, it was clear that children experienced nearly all health actions listed in the sixth-, ninth-, and twelfth-month appointments.

In all seven recommended visits, the Northeast region stood out for demonstrating the highest prevalence of quality in childcare, contrary to the study hypothesis, and showing adequate performance of health services in the Brazilian territory. In the adjusted analysis, the high quality infant care outcome was also higher in the Northeast ( $\mathrm{PR}=1.17,95 \% \mathrm{CI} 1.09-1.26$ ). The explanation for this finding may be the fact that the Northeast region was the first to have the Program of Community Health Agents (PCHA) in the 1990s, and later the Family Health Program (FHP), currently named FHS ${ }^{22}$.

Over the years, the consolidation of the FHS program in the Northeast may have contributed to the current evidence of higher quality childcare services in that region. Possibly, health professionals of the FHS have more training, such as continuous education and residency courses in family healthcare, which qualify them to offer proper care and work in a multidisciplinary way, resulting in fulfillment of protocols and better performance in health services ${ }^{2}$. The expansion of the FHS program from 1999 to 2004 was more solid in the Northeast, in comparison to the South ${ }^{13}$. According to the 2008 National Household Survey, the proportion of residents enrolled in FHS units was higher in the Northeast (67.7\%) rather than in the South (53.0\%). According to the 2013 National Health Research, the Northeast region also had the highest percentage of residents in households registered in FHS units, $68.1 \%$, in relation to other regions of Brazil; the South, for example, had $58.4 \%^{17}$.

The FHS contributed over the years to expand health services in small towns and outlying areas of major cities $^{22}$, showing better results regarding the recommended actions carried out in the family health program when compared to traditional primary care ${ }^{2,13}$. These findings meet the results described herein, which revealed the highest quality of childcare among smaller municipalities ( $\mathrm{PR}=1.17,95 \% \mathrm{CI} 1.03-1.33$ ) and among those with 50,000-99,999 inhabitants (PR $=1.20,95 \%$ CI 1.09-1.34).

When analyzing the (unpublished) data of 220 health units in the South and Northeast regions, there were no differences in physical structure, inputs, human resources, and work process.

The adjusted analysis did not demonstrate the association of high quality infant care with variables linked to economy, mothers, and children. This result indicates that, in primary care, especially in infant care services, there seems to be no influence of these issues on the quality of infant healthcare, which strengthens health equity. This may be related to the expansion of the FHS throughout the country, which has particularly affected small municipalities, characterized by lower socioeconomic development ${ }^{22}$. According to Malta et al. ${ }^{17}$, in Brazil and in all regions, the FHS coverage has been higher in lower education areas, both regarding the proportion of registered individuals and home visits by a community health worker or team member. However, there is no denying that the existence of barriers, triggered by inadequate organization of healthcare services and by regional differences, interfere in the quality of care ${ }^{14}$.

It is important to underline that this study has limitations because of the research instrument, as it did not explore the reasons related to the low prevalence of some variables, such as instruction on breastfeeding, identified in the first-week appointment, and it does not address information about the neuropsychomotor development of the child. Another aspect to be observed is due to the sample procedure, since mothers of several children from the same family could get confused and switch information about their children. In order to minimize this problem, the interviewer was instructed to follow the individual script, according to the number of children in the residency. There is still the possibility of memory bias in the mothers' interview. To avoid such risk, we collected only the information on appointments carried out with children aged under one year old.

This study gathered information using a household survey answered by the mothers about the care and instruction on infant care. These results reinforce the need to achieve complete 
and proper care services for children throughout their first year of life. Moreover, they point out the Northeast region as the highest in quality of infant care, possibly influenced by the consolidation of the FHS program in that territory.

\section{REFERENCES}

1. Alves CRL, Lasmar LMLBF, Goulart LMHF, Alvim CG, Maciel GVR, Viana MRA, et al. [Quality of data on the Child Health Record and related factors]. Cad Saude Publica. 2009;25(3):583-95. Portuguese. https://doi.org/10.1590/S0102-311X2009000300013

2. Arantes LJ, Shimizu HE, Merchán-Hamann E. The benefits and challenges of the Family Health Strategy in Brazilian Primary Health care: a literature review. Cienc Saude Coletiva. 2016;21(5):1499-510. https://doi.org/10.1590/1413-81232015215.19602015

3. Ashworth A, Shrimpton R, Jamil K. Growth monitoring and promotion: review of evidence of impact. Matern Child Nutr. 2008;4 Suppl 1:86-117. https://doi.org/10.1111/j.1740-8709.2007.00125.x

4. Barata RB, Ribeiro MCSA, Moraes JC, Flannery B. Socioeconomic inequalities and vaccination coverage: results of an immunisation coverage survey in 27 Brazilian capitals, 2007-2008. J Epidemiol Community Health. 2012;66(10);934-41.

5. Caldeira AP, Oliveira RM, Rodrigues OA. [Quality of maternal and child health care in different models of Primary Health Care]. Cienc Saude Coletiva. 2010;15 Supl 2:3139-47. Portuguese. https://doi.org/10.1590/S1413-81232010000800018

6. Carvalho MF, Lira PIC, Romani SAM, Santos IS, Veras AACA, Batista-Filho M. [Monitoring of infant growth by health services in Pernambuco State, Brazil]. Cad Saude Publica. 2008;24(3):675-85. Portuguese. https://doi.org/10.1590/S0102 311X2008000300021

7. Cesar JA, Chrestani MAD, Fantinel EJ, Gonçalves TS, Neumann NA. [Child health in poor areas: findings from a population-based study in Caracol, Piauí, and Garrafão do Norte, Pará, Brazil]. Cad Saude Publica. 2009;25(4):809-18. Portuguese. https://doi.org/10.1590/S0102-311X2009000400012

8. Costa GD, Cotta RMM, Reis JR, Ferreira M LSM, Reis RS, Franceschini SCC. [Evaluating child healthcare in the context of Family Healthcare in the city of Teixeiras, Minas Gerais (MG, Brazil)]. Cienc Saude Coletiva. 2011;16(7):3229-40. Portuguese. https://doi.org/1590/S1413-81232011000800022

9. Costa JSD, Cesar JA, Pattussi MP, Fontoura LP, Barazzetti L, Nunes MF, et al. [Child healthcare: completion of health records in municipalities in the semiarid region of Brazil]. Rev Bras Saude Matern Infant. 2014;14(3):219-27. Portuguese. https://doi.org/10.1590/S1519-38292014000300003

10. Costa JSD, Cesar JA, Weber AP, Garcez AS, Nora CRD, Rower HB, et al. [The characteristics of children under five years of age receiving basic care services in two municipalities in the Northeast region of Brazil]. Rev Bras Saude Matern Infant. 2015;15(1):33-46. Portuguese. https://doi.org/10.1590/S1519-38292015000100003

11. Cunha CLF, Silva RA, Gama MEA, Costa GRC, Costa ASV, Tonial SR. [The use of primary attention services to health by the childhood population in a Brazilian northeast]. Cad Saude Coletiva. 2013;21(2):115-20. Portuguese. https://doi.org/10.1590/S1414-462X2013000200003

12. Damasceno SS, Nóbrega VM, Coutinho SED, Reichert APS, Toso BRGO, Collet N. Children's Health in Brazil: orienting basic network to Primary Health Care. Cienc Saude Coletiva. 2016;21(9):2961-73. https://doi.org/10.1590/1413-81232015219.25002015

13. Facchini LA, Piccini RX, Tomasi E, Thumé E, Silveira DS, Siqueira FV, et al. [Performance of the PSF in the Brazilian South and Northeast: institutional and epidemiological assessment of Primary Health Care]. Cienc Saude Coletiva. 2006;11(3):669-81. Portuguese. https://doi.org/10.1590/S1413-81232006000300015

14. Fausto MCR, Giovanella L, Mendonça MHM, Seidl H, Gagno J. [The position of the Family Health Strategy in the health care system under the perspective of the PMAQ-AB participating teams and users]. Saude Debate. 2014;38 No Espec:13-33. Portuguese. https://doi.org/10.5935/0103-1104.2014S003

15. Jaime PC, Frias PG, Monteiro HOC, Almeida PVB, Malta DC. Healthcare and unhealthy eating among children aged under two years: data from the National Health Survey, Brazil, 2013. Rev Bras Saude Matern Infant. 2016;16(2):149-57. https://doi.org/10.1590/1806-93042016000200005 
16. Kirkwood BR, Jonathan ACS. Essential medical statistics. 2.ed: Medford (Mass): Wiley-Blackwell; 2003.

17. Malta DC, Santos MAS, Stopa SR, Vieira JEB, Melo EA, Reis C, et al. Family Health Strategy Coverage in Brazil, according to the National Health Survey, 2013. Cienc Saude Coletiva. 2016;21(2):327-38. https://doi.org/10.1590/1413-81232015212.23602015

18. Marinho LMF, Capelli JCS, Rocha CMM, Bouskela A, Carmo CN, Freitas SEAP, et al. Situation of the supplementary diet of children between 6 and 24 months attended in the Primary Care Network of Macaé, RJ, Brazil. Cienc Saude Coletiva. 2016;21(3):977-86. https://doi.org/10.1590/1413-81232015213.06532015

19. Mesquita Filho M, Luz BSR, Araújo CS. [Primary health care and its attributes: the situation of children under two years of age according to their caregivers]. Cienc Saude Coletiva. 2014;19(7):2033-46. Portuguese. https://doi.org/10.1590/1413-81232014197.17322013

20. Ministério da Saúde (BR), Secretaria de Atenção à Saúde, Departamento de Atenção Básica. Saúde da criança: crescimento e desenvolvimento. Brasília (DF); 2012 [cited 2017 Oct 25]. (Cadernos de Atenção Básica, 33). Available from: http://bvsms.saude.gov.br/bvs/publicacoes/saude_crianca_crescimento_desenvolvimento.pdf

21. Onis MD. Preventing childhood overweight and obesity. J Pediatr (Rio J). 2015;91(2):105-7. https://doi.org/10.1016/j.jped.2014.10.002

22. Paim J, Travassos C, Almeida C, Bahia L, Macinko J. The Brazilian health system: history, advances, and challenges. Lancet. 2011;377(9779):1778-97. https://doi.org/10.1016/S0140-6736(11)60054-8

23. Santos RCK, Resegue R, Puccini RF. Childcare and children's healthcare: historical factors and challenges. J Hum Growth Dev. 2012 [cited 2017 Oct 25];22(2):160-5. Available from: http://pepsic.bvsalud.org/pdf/rbcdh/v22n2/06.pdf

24. Silva JM, Caldeira AP. [Health care model and quality indicators: perceptions of primary health care professionals]. Cad Saude Publica. 2010;26(6):1187-93. Portuguese. https://doi.org/10.1590/S0102-311X2010000600012

25. Victora CG, Aquino EM, Leal MC, Monteiro CA, Barros FC, Szwarcwald CL. Maternal and child health in Brazil: progress and challenges. Lancet. 2011;377(9780):1863-76. https://doi.org/10.1016/S0140-6736(11)60138-4

26. Victora CG, Bahl R, Barros AJ, França GV, Horton S, Krasevec J, et al. Breastfeeding in the 21st century: epidemiology, mechanisms, and lifelong effect. Lancet. 2016;387(10017):475-90. https://doi.org/10.1016/S0140-6736(15)01024-7

Authors' Contribution: Design and planning of the study: LAF, ET. Analysis and interpretation of the data: ASS, SMSD, ET. Elaboration or revision of the study: ASS, SMSD, NVC, ET. Approval of the final version: LAF, ET.

Conflict of Interest: The authors declare no conflict of interest. 